\title{
Dynamics of Risk Factors Affecting the Capital Adequacy Ratio with Special Reference to UCO Bank
}

\author{
Preeta Sinha $^{1 *}$ and Protik Basu ${ }^{2}$ \\ ${ }^{1}$ Assistant Professor, ${ }^{2}$ Associate Professor \\ ${ }^{1 \& 2}$ Army Institute of Management, Judges Court Road, Alipore, Kolkata, West Bengal, India \\ E-Mail: preeta.sinha@aim.ac.in,protik.basu@aim.ac.in
}

\begin{abstract}
To reinforce the stability of the financial system, policy makers and the Basel committee have proposed Basel accord to ensure that financial institutions maintain sufficient capital buffers. Basel III framework emphasizes on sustained increase in bank capital in order to absorb the potential credit, market and operational risks. The capital adequacy requirement under Basel III norms are directly linked to the PCA (Prompt Corrective action) framework which has disrupted the flow of credit in the economy. Market risk, Credit risk, Operational risk and deposits are some of the factors affecting the capital adequacy ratio (CAR) which influences the bank performances. This study aims at analysing the most important factor responsible for the shrinking liquidity due to adherence of stringent capital adequacy ratio imposed by $\mathrm{RBI}$. Currently 11 public sector Banks out of 21 PSUs under PCA has sequentially shrunk their loan book including UCO Bank. The bank's asset quality has worsened over the years. Using regression analysis, this paper seeks to study the major determinants of Capital Adequacy ratio using data sets for the period from 2009 to 2018 of UCO bank. The data was collected from the financial reports of the UCO bank for the aforesaid period. Among the parameters considered, it was found that deposits affect the CAR the most and market risk has the lowest impact on CAR.
\end{abstract}

Keywords: Capital Adequacy Ratio, Basel Norms, Credit Risk, Market Risk

\section{INTRODUCTION}

The present banking sector crisis in India is creating a domino effect in the economy. The major issues affecting the lenders are the mounting Nonperforming assets or bad loans which are worth Rs. 9.61 trillion by the end of 2017 and the ultimately eroding the capital of the banks. Weak capital and elevated non-performing assets have marred Public sector Banks lending appetite. The Government as well as the Regulator Reserve bank of India is taking corrective actions time and again. Recapitalisation of Banks and Prompt corrective action against the banks unable to adhere to certain strict parameter laid down by RBI are the major steps in this regard. The major cause of Current banking system is a huge asset liability mismatch due to lack of flourished bond market in India, in the absence of which banks are forced to lend to long gestation infra project. When these projects run into hurdle, their difficulties percolate into the difficulties of banks. Thus the banks are exposed to credit risk which is affecting its overall performance. The increased volatility in the financial market makes a significant impact on the financial soundness of the banks. The market risk arises due to volatility in the market poses risk of losses in on and off balance sheet positions of the bank. It is most prominent for banks involved mostly in investment. The major components of market risk include market risk, equity risk, Foreign exchange risk and commodity risk. Along with Credit risk and Market risk banks are also exposed to operational risk which is the risk of loss resulting from inadequate or failed internal processes, people and system or from external events. The PNB fraud scandal of Nirav Modi and Mehul Choksi in the recent past is one of the instances of operational risk which have long lasting repercussions on the broader economy. Almost all departments in banks are affected by operational risk. The credit; Investment, treasury as well as the information technology are not isolated one from this risk. The collapse of Britain's Barings bank in 1995 is an appropriate example in this regard.

To strengthen the regulation, supervision and risk management in banks across countries after the globalisation era Basel norms were developed by the Basel committee on Banking Supervision-BCBS (1988).It is a global regulatory framework for more resilient banks and the banking system. The purpose of the accord is to ensure that financial institutions have enough capital on account to meet obligations and absorb unexpected losses. India has also accepted Basel accords for the banking system. According to Basel III norms the minimum capital adequacy ratio (CAR) that banks must maintain is $8 \%$. The capital adequacy ratio is a measure of a bank's capital to its risk weighted assets. The capital is divided into two partsTier-1 Capital and Tier-2 capital.Tier-1 Capital is the core capital which comprises of equity capital, ordinary Share Capital, Intangible assets and audited Revenue reserves. The Tier-2 capital which is also called supplementary capital comprises unaudited retained earnings, unaudited reserves and general loss reserves. This capital absorbs losses in the event of the company winding up its assets or liquidating. The risk weighted assets (RWA) represents its assets, weighted by their riskiness which comprises of all the risks. The capital to risk weighted assets ratio promotes financial stability and efficiency in the economic system.

$$
\mathrm{CAR}=\frac{\text { Total Capital (Tier I capital }+ \text { Tier II capital) }}{\text { Total Risk Weighted Assets }} \times 100
$$


Banks with higher capital adequacy ratio are preferred in terms of safety and financial stability. The Indian scheduled banks are required to maintain a CAR of $9 \%$ while Public Sector banks are emphasised to maintain a CAR of $12 \%$ as per the RBI norms. The stringent than global norms is debilitating the bank's lending capacity and income generation. To give some breather to the tumbling banking sector RBI had extended the deadline for lenders to lift the capital conservation buffer by March 31, 2020 but retained the same requirement for capital adequacy ratio.

RBI effort to resurrect weak Banks by bringing them under Prompt corrective actions (PCA) framework is not showing any significant reduction in the Gross non-performing assets of the 11 Banks out of 21 state run Banks. Though some banks have improved their profitability, UCO Bank along with IDBI bank, Allahabad bank and Dena Bank has reported deterioration in both Profitability and NPA. UCO Bank is India's one of the relevant Public Sector Bank. But in the last couple of years it has been observed that the performance of UCO Bank has been deteriorated drastically. Not much improvement has been observed after taking several measures.

The factors which led to downfall are: Increasing losses, Increasing cost of the bank compared to its income, smaller percentage of current \& savings deposits as compared to total deposit which resulted in lesser amount of interest income for the bank, and Decrease in Return on Equity and Earning per Share. The credit risk which is taken as a certain proportion of Advances and the market risk as that of Investment affect the CAR. The operational risk is taken as indicative of weakness in internal controls and audits, risk management framework, and governance mechanism at bank. The extent of their influence varies with the risk taken into consideration. This paper is an attempt to determine the variables which establish a strong relationship with CAR.

\section{REVIEW OF LITERATURE}

Ariss and Sarieddine (2007) highlighted serious issues related to risk management and the nature of risks arising from the uses of funds of Islamic financial institutions and their implication on the Islamic financial institution. They stressed that other challenges lie ahead of international regulatory bodies in order to cater to other types of risks that are unique to Islamic financial institutions.

Kleff and Weber (2008) stressed that the capital level is positively correlated with the profit of the bank. Therefore, the accumulation of the profits provides a higher level of capital growth.

Dániel (2009) conducted analysis on the operational risk aspects of the introduction of the capital adequacy regulation which came into force in the Hungarian banking system in line with Basel II. The author concluded that the conscious management of operational risk and application of more developed methods aimed at managing such risks can contribute to the stability of the financial system.

Odunga \& Nyangweso (2013) in their study investigated the effects of credit risk and capital adequacy measures on operating efficiency of commercial banks in Kenya. The study concluded that the operational efficiency and risk based capital ratio are positively and significantly affected by bank's operating efficiency and banks should seek mechanisms to improve their risk based capital ratio in order to improve operating efficiency and remain competitive in the market.

John \& Anna (2015) studied the impact of extreme events on the loan portfolios of the Greek banking system. The results show an increase of credit risk during the crisis periods, and the differentiation of risk depending on the size of the banking organization as well as the added capital that will be needed in order to hedge that risk.

Huey-Yeh \& Hsiao-Yi (2016) explored whether the effects of risk management factors on the operational performance of banks differed between the two operational methods. The results showed that the banks could enhance their operational performance by managing risks and the effects of the risk management factors on their operational performance differed between the operational methods.

Rufo \& John (2017) has examined the credit risk and capital adequacy of the rural banks in the Philippines to investigate how variables affect bank profitability. The analysis showed that capital adequacy has no significant impact on the profitability of rural banks in the Philippines and it is therefore necessary for the rural banks to examine more deeply if capital infusion would result in higher profitability than increasing debts.

Gabriel \& Ene (2018) found that the Capital Adequacy Ratio is largely determined by banks risk-portfolio, deposit level, profitability and asset quality. They concluded that the Deposits level and profitability are positively related \& Asset Quality Ratio is negatively related to Capital Adequacy Ratio.

\section{OBJECTIVES OF THE STUDY}

The objective of this research is to determine the degree of influence of the Credit Risk, Market Risk, Operational Risk and Deposits on Capital Adequacy Ratio, with special reference to UCO Bank.

\section{RESEARCH METHODOLOGY}

In this research descriptive analysis and Linear regression analysis is used to examine the correlation and the degree of strength between capital adequacy ratio (dependent variable) and the different Risksi. e, Market Risk (MR), Credit Risk(CR) and Operational Risk (OR) and Deposits (DEP). Bank's capital adequacy ratio and its determinants 
will be processed using SPSS 20 version. To analyse the relationship between the capital adequacy ratio and its determinants, a model is required to do regression analysis.
The following econometric model is created in order to find the significance relationship of CR, MR, and DEP on the dependent variable.

CAR $=\beta_{0}+\beta_{1}$ MARKET RISK $+\beta_{2}$ CREDIT RISK $+\beta_{3}$ OPERATIONAL RISK $+\beta_{4}$ DEPOSITS $+\epsilon_{000}$

\section{DATA ANALYSIS AND INTERPRETATION}

Statistical software is used to find the correlation between capital adequacy ratio and its determinants.

TABLE I DESCRIPTIVE ANALYSIS

\begin{tabular}{|l|c|c|c|c|c|}
\hline \multicolumn{7}{|c|}{ Descriptive Analysis } \\
\hline & CAR & MR & CR & OPR & DEP \\
\hline Mean & 12.17 & 9754.6 & 82847.5 & 8124.8 & 169947.1 \\
\hline Maximum & 14.15 & 19179 & 105682 & 13280 & 214337 \\
\hline Minimum & 9.63 & 4457 & 50199 & 3477 & 100222 \\
\hline Std, Dev & 1.38 & 4640.08 & 17859.52 & 3772.85 & 38509.6 \\
\hline Skewness & -0.392 & 0.935 & -0.686 & 0.180 & -0.652 \\
\hline Kurtosis & -0.249 & 0.254 & -0.405 & -1.656 & -0.696 \\
\hline
\end{tabular}

The table I above shows that the capital adequacy ratio of UCO bank is 12.17 which imply that it has maintained the CAR norms laid by RBI. The standard deviation of 1.38234 indicates a small variation of the individual values, while in case of MR and OPR the deviation from the mean is $47.5 \%$ and $46.44 \%$ respectively. The Std. Deviation of CR $(21 \%)$ and DEP (22.6\%) are quite less as compared to MR and OPR. The high volatility in the market affects the value of the investments which ultimately influence the market risk of the bank.

TABLE II PEARSON CORRELATION

\begin{tabular}{|l|c|c|c|c|c|}
\hline \multicolumn{7}{|c|}{ Pearson Correlation } \\
\hline & CAR & MR & CR & OPR & DEP \\
\hline CAR & -- & -- & -- & -- & -- \\
\hline MR & -0.816 & -- & -- & -- & -- \\
\hline CR & -0.278 & 0.567 & -- & -- & -- \\
\hline OPR & -0.733 & 0.899 & 0.702 & -- & -- \\
\hline DEP & -0.416 & 0.734 & 0.956 & 0.855 & -- \\
\hline
\end{tabular}

Table II depicts that there is strong negative correlation between CAR and MR (-0.8160). The negative relation is mainly due to the severe volatility in the stock market which ultimately affects the CAR of the Bank. Highly positive correlations are seen between CR and DEP on the premise that banks receive money as deposits from depositors which is used for lending. In case too many economic projects funded with loans yield insufficient funds or even defaults, the credit risk increases.

TABLE III ANOVA

\begin{tabular}{|l|c|c|c|}
\hline R square & Adjusted R Square & Sig & Durbin Watson \\
\hline 0.875 & 0.775 & $0.018^{*}$ & 2.107 \\
\hline \multicolumn{4}{|c|}{ *Sig at 5\% level of significance }
\end{tabular}

The value of adjusted R-Square is 0.775 , which means that about 77.5 percent of variation in Capital adequacy ratio is explained jointly by Market Risk, Credit Risk, Operational Risk and Deposits. The values are statistically significant $(\mathrm{sig}=0.018)$ at $95 \%$ confidence level. The value of Durbin Watson (2.107) is close to 2 which state that there is no autocorrelation in the sample.

TABLE IV COEFFICIENTS

\begin{tabular}{|l|c|c|c|}
\hline & $\begin{array}{c}\text { Unstandardized } \\
\text { Coefficients }\end{array}$ & $\begin{array}{c}\text { Standardized } \\
\text { coefficients } \\
\text { Beta ( } \beta)\end{array}$ & Sig \\
\hline Constant & 11.586 & & \\
\hline MR & & -0.849 & $0.073 * *$ \\
\hline CR & & -1.529 & 0.129 \\
\hline OPR & & -1.196 & $0.082 * *$ \\
\hline DEP & & -2.691 & $0.065 * *$ \\
\hline
\end{tabular}

The standardised coefficients $\beta$ represents the values of the regression .It compares the magnitude of the coefficients to see which one has more of an effect. Deposits (DEP), Market risk (MR) and Operational risk (OPR) are found to be significant at $90 \%$ level of confidence. The coefficient of Deposits (-2.691) is highest among all the variables implying that it is playing a major role in affecting the CAR. Next to deposits is the Credit Risk (-1.529) which is clear indication of the increasing default risk in the Banks. Thus the model can be written as:

\section{$\mathrm{CAR}=11.586-0.849 \mathrm{MR}-1.529 \mathrm{CR}-1.196 \mathrm{OPR}-2.691 \mathrm{DEP}+\epsilon_{0}$}

\section{FINDINGS AND ANALYSIS}

The role of Deposits in influencing the CAR is more as compared to Market risk, Credit risk and operational risk. The largest source of funds for Banks is Deposits .It though incur expense but generate revenue in the form of loan interest which is income for the bank. The second most influencing factor is the credit risk (-1.529). The mounting default risk is one of the main reasons behind the Prompt corrective Framework. The market risk and operational risk are highly positively correlated. The volatility in the financial market determining the market risk affects the operational risk.

Highly positive correlation is seen between CR and DEP on the premise that banks receive money as deposits from depositors which is used for lending. In case too many economic projects funded with loans yield insufficient funds or even defaults, the credit risk increases. The standard deviation of Market risk and Operational risk is attributed to extreme fluctuations in the market. 


\section{CONCLUSION}

It is observed from our study that Deposits and Credit risk are the most influencing factors affecting the CAR of UCO Bank. The credit creation is drastically decreasing in UCO bank as they are largely confined to retail, mortgages and small loans. The recent restrictions by RBI in the form of PCA have worsened the situation. Inthe wake of the turmoil in the banking sector where RBI is taking every corrective action to streamline the industry, banks are continuously encouraged to avoid risky activities, improve operational efficiency and focus on conserving capital. The fluctuations in the market risk and operational risk is observed to be on the higher side. The market risk which arises due to the investments need to be managed and supervised by the professionals. Innovative ways to shield the institutions from cyber threats is the need of the hour as it affects the operational risk of the banks.

The study recommends that the bank should create an environment which leads to creation of innovative financial services leading to increased financial performance and growth of the sector hence capital adequacy. Improved and Innovative capability should be the key focus area of the commercial banking sector in order to enhance capital adequacy.

The financial Sector has far reaching implications on the health of the economy. Crumbling asset Quality of banks, declining capital is eroding the profitability of the banks. The new risk based regulatory framework such as tighter definition of regulatory capital, higher risk weighted requirements, a new minimum leverage ratio and a capital conservation buffer is further strengthening the regulatory mechanism.Visualizing the risk, combating the adverse effects on profitability through proactive planning and ensuring the implementation of the risk management process has assumes pivotal significance.

\section{REFERENCES}

[1] Ariss, R. T. \& Sarieddine, Y. (2007). Challenges in implementing capital adequacy guidelines to Islamic banks, Journal of Banking Regulation, 9(1), 46-59.

[2] RBI Report (2018). RBI Report on trend and Progress of banking in India (2017-18).

[3] Odunga, R. M. \& Nyangweso P. M. (2013). Credit Risk, Capital Adequacy and Operating Efficiency Of Commercial Banks in Kenya, International Journal of Business and Management Invention, 6-12.

[4] Leventides, J. \& Anna, D. (2015). The Impact of the Basel Accord on Greek Banks: A Stress Test Study, Journal of Risk and Financial Management, 181-197, Retrived from http://doi:10.3390/jrfm8020181

[5] Murithi, J. G., Waweru, K. M. \& Muturi, W.M. (2016). Effect of credit risk on Financial Performance of commercial Banks Kenya, IOSR journal of Economics and Finance, 7(4), 72-83, Retrieved from: http://doi: 10.9790/5933-0704017283.

[6] Lin, Huey-Yeh. \& Chang, Hsiao-Yi. (2016). Analysis of the Correlation between Operational Risks and Operational Performance: Results obtained by comparing Independent Banks with the Financial Holding Subsidiary Banks, International Journal of Business and Commerce. 4(8), 1-16.

[7] Homolya, D. (2009). The impact of the capital requirements for operational risk in the Hungarian banking system, MNB Bulletin

[8] Gabriel O Abba \& Okwa, E. (2018), Determinants of Capital Adequacy Ratio of Deposit Money Banks in Nigeria, Journal of Accounting \&Marketing, 7(2), 1-7, Retrieved from: http://doi: 10.4172/2168-9601.1000271.

[9] Mendoza, R., \& Paolo, J. (2017). The Effect Of Credit Risk And Capital Adequacy On The Profitability Of Rural Banks In The Philippines, Scientific Annals of Economics and Business, 64(1), 8396, Retrieved from: http://: 10.1515/saeb-2017-0006.

[10] Raharjo, P. G., Hakim, D. B., Manurung, A. H. and Maulana, T. N. A. (2014). Determinants of capital ratio: a panel data analysis on state-owned banks in Indonesia, Bulletin of Monetary, Economics and Banking, 16(4), 395-414.

[11] Leventides, J., \& Donatou, A. (2015). The Impact of the Basel Accord on Greek Banks: A Stress Test Study, Journal of Risk and Financial Management, 8(1), 181-197, Retrieved from: http://: doi:10.3390/jrfm8020181.

[12] Muriithi, J. G., \& Waweru, K. M, (2016). Effect of Credit Risk on Financial Performance of Commercial Banks Kenya, IOSR Journal of Economics and Finance, 7(4), 72-83.

[13] Ansary, O. (2015). Determinants of capital adequacy ratio: An empirical study on Egyptian banks, Corporate ownership and control, 13(1), 806-816. 